\title{
Supplementary non pharmacological interventions in patients of the Department of Oral and Maxillofacial Surgery
}

\author{
Sabine Sailer \\ From Safety in hospitals: from strategy to implementation Annual Scientific Meeting 2015 \\ Graz, Austria. 29-30 September 2015
}

\section{Background}

Dental surgery is performed under local anesthesia. By introducing methods, which are able to reduce pain, dental procedures have lost much of its fear factor.

Nevertheless, patient reports of unpleasant sensations up to severe pain (according to surveys between 60\% to $80 \%)$ still cause fear of dental procedures [1].

Preoperative anxiety had a negative impact on case studies in postoperative pain intensity [2]. Sartory et al., (2010) reported $20 \%$ of the patients that they are very anxious and therefore $5 \%$ even avoid the dentist. Anxiety and pain are the reason for the worsening of dental status of patients and leads to health problems and social impairment [3].

For these reasons, pain management is an important prerequisite to facilitate the treatment situation for the patient and to avoid far-reaching consequences. Some patients use non-pharmacological methods during surgery under local anesthesia in oral surgery. These interventions must be structured and individualized to each patient to offer maximum pain relief with minimal side effects. To better address these needs, a patient survey was performed.

\section{Material and methods}

Based on literature search a patient questionnaire was designed. By interviewing our patients any preferences should be recognized. A descriptive, quantitative crosssectional design was chosen, multiple answers were possible.

Correspondence: sabine.sailer2@klinikum-graz.at

Division of Oral and Cranio-Maxillofacial Surgery, Department of Dentistry and Maxillofacial Surgery, Medical University of Graz, Austria

\section{Results}

Of all respondents, $43.2 \%$ wanted additional calming measures prior to treatment. $54.1 \%$ requested additional calming measures during treatment. 22 patients from outpatient care and 18 from operating activities required additional measures during treatment. The other 14 patients surveyed from the outpatient and 20 from operations did not request any complementary interventions.

Requested pre-treatment information was primarily about calming measures (30.3\%), followed by treatment related information $(27.0 \%)$. Music was preferred in $18.9 \%$ and breathing exercises in $8.2 \%$. Jin Shin Jitsu was used in $6.6 \%$, the anti-stress ball in $4.9 \%$, and muscle relaxation in $4.1 \%$. Music from the radio was preferred primarily (50\%) followed by classical music $(30.8 \%)$ and modern music (19.2\%).

\section{Conclusions}

Our investigation showed that an increased number of patients requested additional calming, interventions even before the planned intervention. Even information about the treatment has a calming effect before and during the procedure. The third most preferred soothing intervention was music, especially of the common radio. Patients expected from non-pharmacological interventions equally calming and pain relief. Further studies are necessary to increase in subjective well-being of patients by using non-pharmacological interventions. This shall optimize patient orientated interventions on a scientifically proven basis.

\section{Acknowledgements}

We thank Chief Nursing Director Christa Tax, MSc, Christine Foussek, MSc, Leo Schröder, MSc, Martin Wiederkumm, MSc and Ingrid Kröll for their support in developing and running the study. 


\section{References}

1. Sartory G, Wannemüller A: Zahnbehandlungsphobie. Göttingen, Bern, Wien, Paris, Oxford, Prag, Toronto, Cambridge, Amsterdam, Kopenhagen, Stockholm: Hogrefe Verlag GmbH\&Co.KG; 2010.

2. \& Stheling: Expertenstandard Schmerzmanagement in der Pflege bei akuten Schmerzen Osnabrück: DNQP; 2011

3. Jäger K: Behandlungsangst beim Zahnarzt Saarbrücken: AV Akademiker Verlag; 2012

doi:10.1186/2056-5917-1-S1-A10

Cite this article as: Sailer: Supplementary non pharmacological

interventions in patients of the Department of Oral and Maxillofacial

Surgery. Safety in Health 2015 1(Suppl 1):A10.

Submit your next manuscript to BioMed Central and take full advantage of:

- Convenient online submission

- Thorough peer review

- No space constraints or color figure charges

- Immediate publication on acceptance

- Inclusion in PubMed, CAS, Scopus and Google Scholar

- Research which is freely available for redistribution

Submit your manuscript at www.biomedcentral.com/submit 